\title{
Individual capacity-building approaches in a global pharmaceutical systems strengthening program: a selected review
}

\author{
Niranjan Konduri ${ }^{1 *}$ (D) Megan Rauscher ${ }^{2}$, Shiou-Chu Judy Wang ${ }^{1}$ and Tanya Malpica-Llanos ${ }^{1}$
}

\begin{abstract}
Background: Medicines use related challenges such as inadequate adherence, high levels of antimicrobial resistance and preventable adverse drug reactions have underscored the need to incorporate pharmaceutical services to help achieve desired treatment outcomes, and protect patients from inappropriate use of medicines. This situation is further constrained by insufficient numbers of pharmaceutical personnel and inappropriate skill mix. Studies have addressed individual capacity building approaches of logistics, supply chain or disease specific interventions but few have documented those involving such pharmacy assistants/professionals, or health workers/ professionals charged with improving access and provision of pharmaceutical services. We examined how different training modalities have been employed and adapted to meet country-specific context and needs by a global pharmaceutical systems strengthening program in collaboration with a country's Ministry of Health and local stakeholders.
\end{abstract}

Methods: Structured, content analysis of training approaches from twelve selected countries and a survey among conveniently selected trainees in Bangladesh and Ethiopia.

Results: Case-based learning, practice and feedback, and repetitive interventions such as post-training action plan, supportive supervision and mentoring approaches are effective, evidence-based training techniques. In Ethiopia and Bangladesh, over $94 \%$ of respondents indicated that they have improved or developed skills or competencies as a result of the program's training activities. Supportive supervision structures and mentorship have been institutionalized with appropriate management structures. National authorities have been sensitized to secure funding from domestic resources or from the global fund grants for post-training follow-up initiatives. The Pharmaceutical Leadership Development Program is an effective, case-based training modality that motivates staff to develop quality-improvement interventions and solve specific challenges. Peer-to-peer learning mechanisms than traditional didactic methods was a preferred intervention among high level government officials both within country and between countries.

Conclusion: Interventions must involve local institutions in the design and delivery of content for both pre-service and in-service training as well as web-based methods where feasible. Such efforts would meet the changing demand in the pharmaceutical system, and promote the ownership of the human capacity development interventions. The cost-effective partnership with universities demonstrate that competency based pre-service training will prepare the future pharmaceutical workforce with a critical foundation of knowledge and skills required to meet the growing demand for patient-centered pharmaceutical services in resource-constrained countries.

Keywords: Human resources, Pre-service training, In-service training, Pharmaceutical systems, Pharmaceutical services, Capacity building

\footnotetext{
* Correspondence: nkonduri@msh.org

'Systems for Improved Access to Pharmaceuticals and Services (SIAPS)

Program, Management Sciences for Health, Arlington, VA, USA

Full list of author information is available at the end of the article
} 


\section{Background}

The Sustainable Development Goal 3.8 of the 2030 Agenda for Sustainable Development specifies that in order to achieve universal health coverage, national development strategies must include "access to safe, effective, quality and affordable medicines and vaccines for all" [1]. The Lancet commission on essential medicines for universal health coverage acknowledged that professionals such as pharmacists and prescribers as well as dispensers need specialized training and information to assure the appropriate use of medicines in the interest of patients and caregivers [2]. Beyond access, medicines use related challenges such as inadequate adherence [3], high levels of antimicrobial resistance [4] and the impact of preventable adverse drug reactions [5] have underscored the need to incorporate patient-oriented pharmaceutical services that help to achieve desired treatment outcomes and protect patients from harm [6, 7]. This situation is further constrained by insufficient numbers of pharmaceutical personnel and incomplete or inappropriate skill mix to respond to the needs of local populations $[8,9]$.

The Systems for Improved Access to Pharmaceuticals and Services program (the 'program') funded by the U.S. Agency for International Development (USAID) works in partnership with local governments and partners to build resilient pharmaceutical systems that deliver safe, timely, and quality pharmaceuticals and healthcare services, through a pharmaceutical systems strengthening approach $[10,11]$. The program's overall capacity building approach was adapted from Potter and Brough's "Pyramid of Effective Needs" and includes nine interrelated components [12, 13]. The components are categorized into individual (performance capacity and personal capacity) and institutional (workload, facility, supervisory, support service, structural, systems, and role capacity). Potter and Brough assert that developing a common definition of capacity building is challenging because of different sociocultural settings. Instead, establishing a hierarchy of capacity-building needs is more useful for designing and implementing activities to address varied capacity gaps.

Pharmaceutical systems in resource-constrained countries are challenged by limited number of institutions for pharmaceutical training and lack of up-to-date training curricula. Using locally relevant and context specific training approaches, the program aims to build and augment individual capacity building interventions to ensure that the pharmaceutical health workforce has the right skill mix and distribution to meet population needs and the appropriate tools to do so. Published studies have addressed individual capacity building approaches of logistics, supply chain [14] or disease specific interventions [15]. However, to our knowledge, from a global program implementer perspective, few have documented the programmatic approach of building individual capacity involving pharmacy professionals, pharmacy assistants or health workers charged with improving access and provision of pharmaceutical services. The objective of this paper is to summarize the various approaches that have been implemented by the program in collaboration with a country's Ministry of Health and local stakeholders, and examine the influence of the training on individual capacity, as defined by Potter and Brough. Using selected, specific country examples, we examined how different training modalities have been employed and adapted to meet country-specific context and needs.

\section{Methods}

Twelve program implementing countries were selected for review based on internal funding availability during the study period June to December 2015: Angola, Bangladesh, Burundi, Cameroon, Democratic Republic of the Congo [DR Congo], Ethiopia, Mali, Namibia, Philippines, South Africa, Swaziland, and Ukraine. We retrieved documentation from the first 3 years of program implementation that was available between 2012 and 2015. We performed a structured, content analysis of training activities from the program's topic specific technical reports, quarterly and annual reports. Internal reports from a one-off training event or multi-event training series were reviewed, which typically provide the training objectives and training methods employed. Country-specific technical reports that contained information on an intervention with a training component were reviewed. After desk review of project documents, each country or portfolio was contacted for the purpose of clarifying content or seeking elaboration on any training methodologies if not documented in sufficient detail. Through our country program, we conducted a survey among conveniently selected trainees in Bangladesh and Ethiopia due to the large number of pharmaceutical personnel trained (Additional file 1 provides details on the methodology). In-country program staff also conducted key informant interviews with 11 authorities in Bangladesh and 19 authorities in Ethiopia who were part of the training initiatives. Institutional permission was obtained from the Ministry of Health personnel based on our country program's ongoing monitoring and evaluation mechanism.

\section{Results}

The program's individual capacity building approaches can broadly be grouped into three categories: pre-service, inservice and proven approaches for individual capacity building. Pre-service training is defined as activities that take place before a person starts a job that requires specific training [16], i.e., before a person "enters service" whereas in-service training is considered training of persons who are already employed, e.g., health care providers working in 
the public or private sector [17]. Drawing upon lessons learned from our predecessor Strengthening Pharmaceutical Systems program (2007-2011) [18], this paper presents the following proven approaches to individual capacity building as applied to either pre-service or in-service training approaches: supportive supervision [19, 20], team based and peer-to-peer learning mechanisms [21, 22], e-learning and blended learning [23]. The program has utilized blended learning models (a combination of face-to-face and virtually facilitated sessions) to scale up the delivery of training activities in a cost-effective, sustainable manner, especially in collaboration with local institutions.

\section{Pre-service training approaches}

A key impediment to the scale-up of pharmaceutical services to address the HIV burden in Namibia was the shortage of skilled pharmaceutical personnel, including pharmacists and pharmacy assistants [24]. To increase the number of qualified pharmaceutical professionals, the program supported two major pre-service activities: the development of a local Bachelor of Pharmacy (B Pharm) degree [25], and revamping accompanying training curricula and supporting the training efforts of the National Health Training Centre (Fig. 1) [26]. By 2014, the number of enrolled B Pharm students increased to 107, and the first 14 graduated received their B Pharm degree in 2015. Details on the process of establishing Namibia's first school of pharmacy is available in the program website $[27,28]$. A wide range of support to improve the quality of pre-service training for B Pharm students and pharmacist assistants was provided, including curriculum revision, recruitment of pharmacy lecturers, information technology assistance, accreditation and quality management system support $[29,30]$.

In DR Congo, the program's partner, the Accreditation Council for Pharmaceutical Education (ACPE) [31], reviewed the pharmacy school curriculum at the University of Kinshasa and developed a road map for updating and implementing a revised curriculum that meets international standards [32]. DR Congo's vision is to prepare competent pharmacists who can better address public health priorities, particularly in the areas of supply chain management, appropriate use of medicines, pharmaceutical services, pharmacovigilance and antimicrobial resistance. National stakeholders recognized this intervention as a high-impact activity with the results spinning off on the other three faculties of pharmacy in the country and the National Pharmacy Council, thereby influencing pharmacy education and practice in the whole country, including the private sector. Thereafter, the program supported the University of Kinshasa to develop a 5-year strategic plan to improve the coordination, monitoring, and evaluation of faculty operations and to develop a competency framework [33], which defines required cognitive, procedural, and behavioral competencies that graduated pharmacists should have upon completion of their degree (Fig. 2) [34].

This competency framework was a major step in overhauling current training curricula and recognized by the USAID's Mission Director in DR Congo (quote): "To improve the pharmaceutical sector, we must address the root of the problem, which is pharmacist training" [35]. Table 1 summarizes key results in Namibia and DR Congo.

\section{In-service training approaches}

Globally, as of December 2015, 35 in-service training curricula had been developed or revised in 11 countries with the program's support. Nearly 39,000 individuals (31\% female, $62 \%$ male) in over 24 countries (Table 2) had been trained in various aspects of pharmaceutical management, including: financing, leadership, regulatory systems, quality assurance, pharmaceutical care, medicine safety, antimicrobial resistance, and supply chain management.

The program seeks to ensure that its capacity-building efforts address immediate country needs to empower and enable country governments and local institutions to develop, implement, and own the technical assistance and capacity-building efforts. Globally, as of December 2015 , the program facilitated 394 local institutions or organizations to provide training or technical assistance in pharmaceutical management.

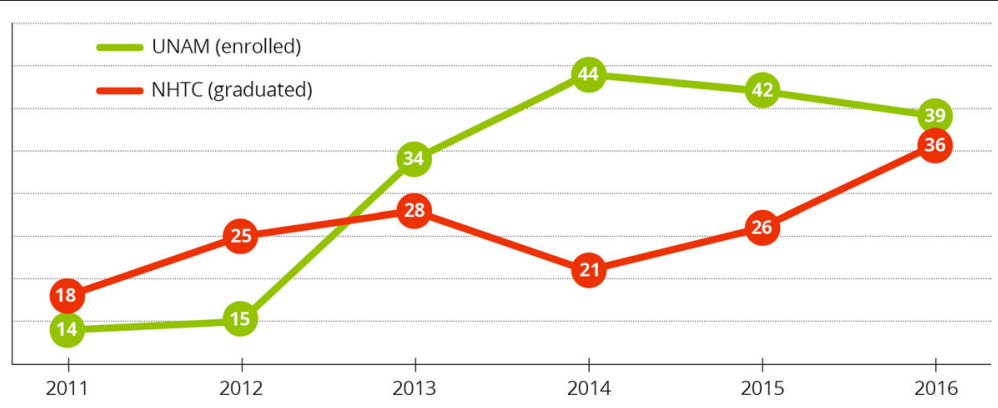

Fig. 1 Number of pharmacist assistants graduating from the National Health Training Center, by year of graduation 


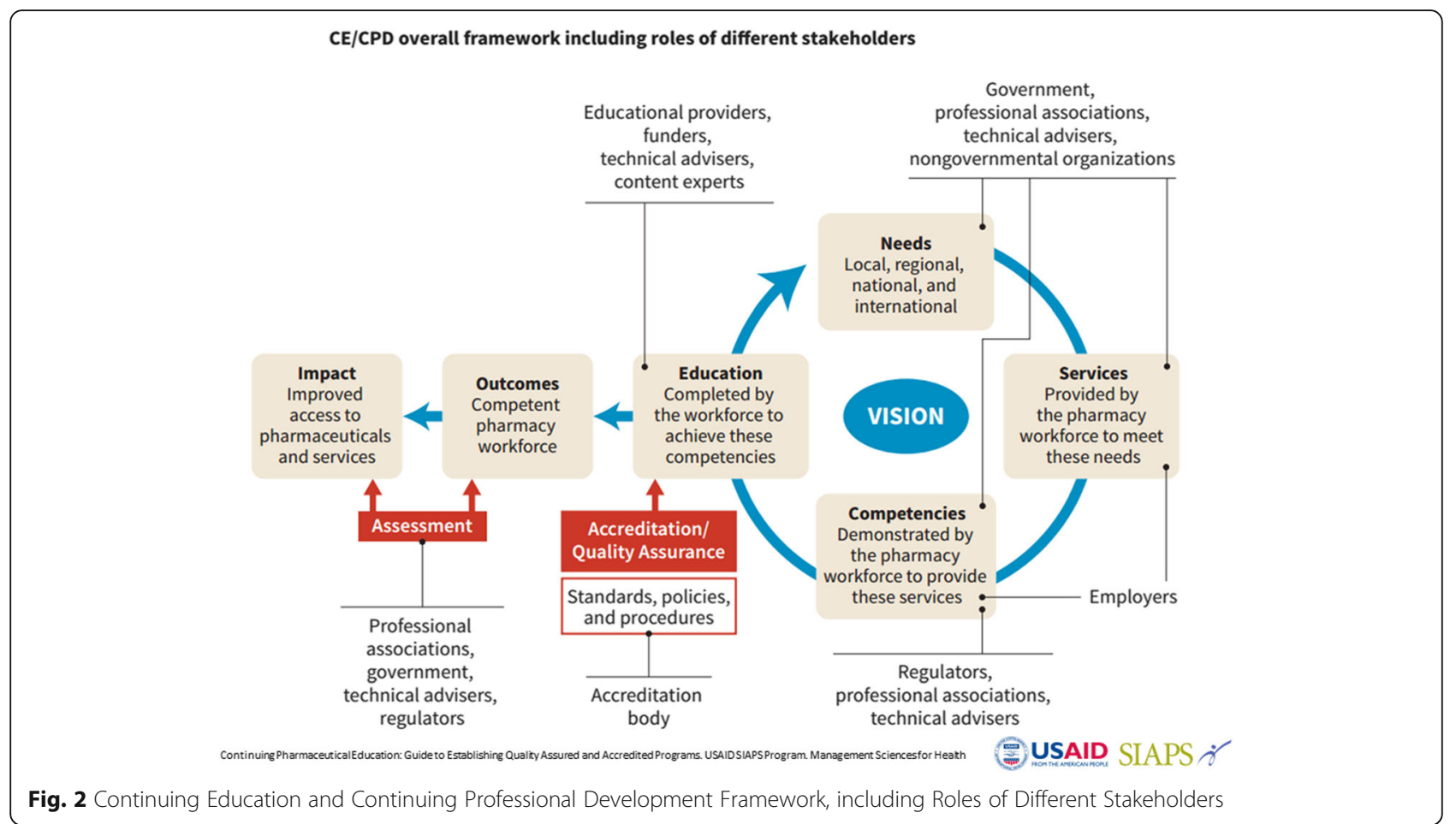

\section{Cascade training approaches}

To strengthen sustainability efforts, the program often employs a cascade training approach to rapidly develop new knowledge or skills in specific pharmaceutical management topics and capacitate national staff in local

Table 1 Relevant Results (Namibia and DR Congo)

\begin{tabular}{|c|c|c|}
\hline & As of December 2015 & Key Results \\
\hline \multirow[t]{2}{*}{ Namibia } & $\begin{array}{l}41 \% \text { increase in the } \\
\text { number of certified } \\
\text { pharmacy personnel }\end{array}$ & \multirow[b]{2}{*}{$\begin{array}{l}\text { - B Pharm and PA } \\
\text { competency framework } \\
\text { developed } \\
\text { - Accreditation for B } \\
\text { Pharm program and PA } \\
\text { courses received } \\
\text { - B Pharm program } \\
\text { launched in } 2011 \\
\text { - The majority (75\%) of } \\
\text { the pharmacist assistants } \\
\text { reported overall } \\
\text { satisfaction with their } \\
\text { PA training at the NHTC } \\
\text { - Over } 90 \% \text { of the } \\
\text { employers and } \\
\text { supervisors were } \\
\text { satisfied with the } \\
\text { pharmacist assistants' } \\
\text { performance at work }\end{array}$} \\
\hline & $\begin{array}{l}97 \% \text { of public health } \\
\text { facilities are staffed with } \\
\text { certified pharmacy } \\
\text { personnel }\end{array}$ & \\
\hline \multirow[t]{2}{*}{ DR Congo } & $\begin{array}{l}1103 \text { persons trained in } \\
\text { pharmaceutical } \\
\text { management }\end{array}$ & \multirow{2}{*}{$\begin{array}{l}\text { Pre-service competency } \\
\text { framework developed } \\
\text { with 5-year strategic } \\
\text { plan }\end{array}$} \\
\hline & $\begin{array}{l}2 \text { health or allied health } \\
\text { professional associations } \\
\text { or councils receiving TA } \\
\text { in pharmaceutical } \\
\text { management education }\end{array}$ & \\
\hline
\end{tabular}

Table 2 Number of Personnel Trained in Pharmaceutical Management, as of December 2015

\begin{tabular}{ll}
\hline Country/portfolio & Number trained \\
\hline Angola & 251 \\
Bangladesh & 15,594 \\
Burundi & 2890 \\
Cameroon & 741 \\
Dominican Republic & 2232 \\
DR Congo & 1103 \\
Ethiopia & 5110 \\
Guinea & 796 \\
Latin America and Caribbean Amazon Malaria Initiative & 554 \\
Lesotho & 438 \\
Mali & 1593 \\
Mozambique & 579 \\
Namibia & 501 \\
Neglected tropical diseases core portfolio & 35 \\
Philippines & 358 \\
South Africa & 1087 \\
South Sudan & 864 \\
Swaziland & 1092 \\
Tuberculosis core portfolio & 2695 \\
Turkmenistan & 22 \\
Ukraine & 280 \\
West Africa Regional & 120 \\
Total & 38,935 \\
\hline &
\end{tabular}


institutions. In an effort to address the high burden of multidrug-resistant tuberculosis, the program and National Tuberculosis Program (NTP) staff piloted training on the e-TB Manager (web-based tool for managing all the information needed by national TB control programs) in three oblasts (states) of Ukraine, which resulted in a decision to scale up the use of e-TB Manager nationwide [36]. Given the country's large size and the resource intensive nature of scale up, a training of trainers (TOT) approach was selected to more efficiently cascade the training across the country. The program engaged a local Ukrainian group specializing in adult learning techniques and TOT methodologies and paired it with NTP staff, with the objective of developing the competencies of oblast-level officials who would run the e-TB Manager educational programs and also assure ownership of the intervention. While interactive methods of training are generally quite new to Ukraine's public-sector health professionals, competency-based methodologies were employed. The TOT session was conducted over a 5-day period, with the first half focusing on adult learning methodologies and the second half on the core technical content of e-TB Manager. A series of six TOT sessions were organized and carried out, involving more than 100 key officials and the NTP program staff. Results of the trainings are summarized in Table 3 [37].

In Mali, essential medicines and health commodities are frequently unavailable at various levels of the health system due to inefficient and poorly coordinated forecasting and quantification processes. To address these challenges, the program intervened to improve the individual capacity of senior leaders and administrators of key pharmaceutical institutions to redesign and roll out an improved Logistics Management Information System (LMIS). Training activities focused on strengthening the technical capacity of managers at all levels in the LMISrelated activities. During training activities, individuals and teams developed plans to support activity implementation. As a key follow-up activity, a joint government and program team visited several health districts to collect information on the status of individual implementation plans. Using coaching and supervision techniques, individual plans were evaluated by the team and

Table 3 Relevant Results (Ukraine)

\begin{tabular}{|c|c|}
\hline By December 2015 & Milestones \\
\hline $\begin{array}{l}225,000 \text { MDR-TB cases were } \\
\text { in the e-TB Manager system }\end{array}$ & \multirow{3}{*}{$\begin{array}{l}\text { - TOT curriculum developed } \\
\text { - E-TB Manager training scaled } \\
\text { up nationally } \\
\text {. Full transfer of the operation, } \\
\text { administration, and development } \\
\text { support of the e-TB manager } \\
\text { was transferred from the } \\
\text { program to the Government of } \\
\text { Ukraine in } 2015\end{array}$} \\
\hline $\begin{array}{l}\text { More than } 100 \text { oblast officials } \\
\text { reached over } 1200 \text { users in } \\
26 \text { oblasts }\end{array}$ & \\
\hline $\begin{array}{l}\text { Consistency between paper-based } \\
\text { and electronically generated } \\
\text { reports was about } 99 \%\end{array}$ & \\
\hline
\end{tabular}

shortcomings addressed. In many of the facilities, trained staff satisfactorily implemented at least one activity in their action plan, including: 1) good storage practices; 2) correct filing; and 3) management and submission of LMIS reports. Table 4 includes selected indicators related to training activities in Mali from 2013 to 2014.

\section{Proven approaches for individual capacity building}

The program has applied participatory, team-oriented learning approaches that incorporate continuous feedback processes and group problem-solving by using local human resources and skillsets. These include task shifting structures, implementing continuous quality improvement measures, engaging the private sector, exploring online learning platforms, and placing an emphasis on effective knowledge sharing and exchange.

\section{Supportive supervision}

The program assists governments and in-country counterparts to design and implement a supportive supervision plan and helps to conduct supportive supervision visits [38]. For example, in Lesotho, the program mentored 24 health care workers in the management of laboratory commodities, and conducted 135 supportive supervision visits to health facilities for LMIS and nutrition assessment counseling in three implementing districts, contributing to improved reporting rates, from 4 to $95 \%$ between two quarters [39]. In Swaziland 12 annual supportive supervision visits and mentorship in

Table 4 Relevant Results (Mali)

\begin{tabular}{ll}
\hline By December 2015 & Milestones \\
\hline 1593 persons trained in & Developed new LMIS that \\
pharmaceutical management & includes the community \\
& level \\
- & Developed training \\
& materials, tools, and job \\
& aids for the new LMIS \\
- & Increased percentage of \\
& stock records that \\
& correspond with physical \\
& counts for a set of indicator \\
& medicines in Ministry of \\
& Health storage and at \\
& health facilities, from 16\% \\
& in 2013 to $42 \%$ in 2014 \\
- & Decreased percentage of \\
& warehouses with stock-outs \\
& of a pre-selected group of \\
& medicines for 3 days or \\
& more in the last 3 months, \\
& from $89 \%$ in 2013 to $66 \%$ \\
& in 2014 \\
Increased percentage of & health facilities that \\
completed and submitted & an LMIS report for the most \\
recent reporting period, \\
from $7 \%$ in 2013 to $33 \%$ \\
in 2014 \\
\hline
\end{tabular}


131 health facilities contributed to increased LMIS reporting rate from $55 \%$ in 2012 to $95 \%$ in 2015 . As a result of improved information quality, national authorities were able to make timely decisions and saved the government close to 6.25 million dollars in unnecessary procurement of medicines and commodities [40].

\section{Peer-to-peer learning mechanisms}

Peer-to-peer learning mechanisms have been applied in specific circumstances. In Ukraine, the program facilitated a practical, interactive training approach rather than employing a traditional didactic method to train individuals in framework contracting in the pharmaceutical sector [41]. In Dnipropetrovsk oblast, authorities launched eight bids in framework contracting; six were successful. Thereafter the program brought the Dnipropetrovsk authorities to Poltava oblast, so that Poltava oblast authorities could hear lessons learned and ask relevant questions from Dnipropetrovsk authorities directly, rather than conducting a formal training program on framework contracting. By facilitating knowledge exchange among high-level government authorities, Poltava oblast authorities learned practical tips and successfully relaunched the tender process in framework contracting after a failed first attempt. The program facilitated a similar approach for high-level government officials in Bangladesh to learn from their peers in India for managing complex World Bank funded selection and procurement of medicines and commodities; and facilitated a partnership with the Korean International Cooperation Agency to enable peer learning with the Korean Ministry of Food and Drug Safety in medicines regulatory systems strengthening.

\section{Electronic information sharing}

The program's approach to capacity building recognizes the growing importance of electronic and new media for widespread access to learning and knowledge exchange [42]. New courses on good governance in the management of medicines and a two-part course on antimicrobial resistance are available on the global health eLearning center [43]. The World Health Organization's dedicated information portal on Essential Medicines and Health Products has more than 5000 pharmaceutical management related documents [44]. In collaboration with the South Africa program, the University of Western Cape developed an online rational medicines use module [45]. An online course for the program's electronic quantification and early warning system (Quan TB) provides access to learning resources with user guides available in six languages [46].

\section{Team-based learning approaches}

To address critical leadership, management and governance skill gaps in South Africa [47], the program applied the Pharmaceutical Leadership Development Program (PLDP). The PLDP brings together health care professionals, including clinicians, pharmacists, facility managers, and operational managers, to strengthen their leadership, management, and governance skills, while engaging them in analyzing a persistent challenge they face at the health facility they serve. Adapted from Management Sciences for Health's Leadership Development Program [48-50], the PLDP is designed to strengthen leadership, governance, and management capacity for health managers in public health service. The PLDP adaption includes additional content on legislation, ethics, governance, financial management, and human resources. It combines pharmaceutical management knowledge and sound leadership practices to better equip pharmacy managers to respond to challenges in their workplaces (Table 5).

An external, independent evaluation of the program stated "the people and institutions [in South Africa] who received this capacity building [including the PLDP] and tools [are] independently capable of managing and making improvements to their programs with minimal technical assistance [...] from the program" [51]. With longterm sustainability in mind, the PLDP/LDP approach has been institutionalized at district and facility levels [52]. Several trained teams have continued to scale up their initial interventions. The management of team mentoring activities has been transitioned from the program to sub-district level teams.

Survey findings from trainees in Bangladesh and Ethiopia Over $94 \%$ of respondents indicated that they have improved or developed skills or competencies as a result of the program's training activities (Fig. 3).

In Bangladesh, an example of systems performance improvements include improved efficiency of supply chain systems in more than 29,000 service delivery points, improved use of data for decision making in 488 subdistricts, and greater customer satisfaction [53, 54]. One respondent stated the following in relation to LMIS [55] training efforts:

\section{"[A] higher authority is now aware, due to the online report, of increased transparency and quality of work; able to identify issues and make timely decisions; improving data quality in LMIS reports though improved inventory management (takes less time, get online [and] on to server easily); timely recovery of information from archive to satisfy information seekers, i.e., audit; etc."}

Key informant interviews with supervisors cited staff performance improvements on reporting data and report preparation, including reduced time required to complete a reporting task and improved accuracy in data entry and 
Table 5 Selected Results from the Pharmaceutical Leadership Development Program (South Africa) [85]

\begin{tabular}{|c|c|c|c|}
\hline Priority Areas & Province & Facility & Results \\
\hline Waiting time & Western Cape & $\begin{array}{l}\text { Kraaifontein Community } \\
\text { Health Centre }\end{array}$ & $\begin{array}{l}\text { Reduced average patient wait time at the } \\
\text { pharmacy from } 41 \text { to } 19 \text { min over a } 6 \text { month } \\
\text { period }\end{array}$ \\
\hline \multirow[t]{2}{*}{$\begin{array}{l}\text { Ensuring medicine } \\
\text { accessibility }\end{array}$} & KwaZulu-Natal & $\begin{array}{l}\text { Umzinto Primary Healthcare } \\
\text { Clinic }\end{array}$ & $\begin{array}{l}\text { Reduced the defaulter rate of patients collecting } \\
\text { pre-dispensed chronic medicine from } 28 \text { to } 23 \%\end{array}$ \\
\hline & Eastern Cape & $\begin{array}{l}\text { Midlands Hospital and } \\
\text { nearby clinics }\end{array}$ & $\begin{array}{l}\text { Developed referral system which facilitated } \\
\text { delivery of chronic diseases medicines from } \\
\text { Midlands Hospital to feeder clinics }\end{array}$ \\
\hline \multirow[t]{2}{*}{$\begin{array}{l}\text { Improving medicine } \\
\text { supply management }\end{array}$} & Eastern Cape & Cecilia Makiwane Hospital & $\begin{array}{l}\text { Implemented a batch management system that } \\
\text { cut the percentage of money wasted due to } \\
\text { expired stock from } 3.8 \% \text { (as a percentage of } \\
\text { expenditure) in April } 2012 \text { to } 0.7 \% \text { in June } 2012 \text {, } \\
\text { which is in keeping with international norms }\end{array}$ \\
\hline & KwaZulu-Natal & Multiple clinics & $\begin{array}{l}\text { Reduced the quantity of expired stock from } 3.4 \% \\
\text { to less than } 0.5 \% \text { of stock holding }\end{array}$ \\
\hline \multirow[t]{2}{*}{$\begin{array}{l}\text { Ensuring compliance } \\
\text { with standards }\end{array}$} & KwaZulu-Natal & $\begin{array}{l}\text { Stanger, Montebello } \\
\text { hospitals and Sundumbili } \\
\text { CHC }\end{array}$ & $\begin{array}{l}\text { Improved compliance with standard treatment } \\
\text { guidelines for prescribing non-steroidal anti- } \\
\text { inflammatory agents from } 57 \text { to } 94 \%, 60 \text { to } 68 \% \text {, } \\
\text { and } 37 \text { to } 67 \% \text {, respectively }\end{array}$ \\
\hline & North West & $\begin{array}{l}10 \text { primary health care } \\
\text { facilities }\end{array}$ & $\begin{array}{l}\text { Increased compliance with national core } \\
\text { standards from } 33 \text { to } 77 \% \text { by developing SOPs, } \\
\text { distributing reference manuals, and building } \\
\text { capacity in good pharmacy practice and } \\
\text { medicine supply management }\end{array}$ \\
\hline \multirow[t]{3}{*}{$\begin{array}{l}\text { Ensuring rational use } \\
\text { of medicines }\end{array}$} & North West & $\begin{array}{l}\text { Joe Morolong Memorial } \\
\text { Hospital }\end{array}$ & $\begin{array}{l}\text { Average number of patients initiated on isoniazid } \\
\text { preventive therapy increased from } 3 \text { to } 8 \text { per } \\
\text { month }\end{array}$ \\
\hline & North West & $\begin{array}{l}\text { Four facilities in Bojanala } \\
\text { District }\end{array}$ & $\begin{array}{l}\text { Increased reporting of adverse drug events from } \\
26 \text { to } 45 \%\end{array}$ \\
\hline & KwaZulu-Natal & $\begin{array}{l}\text { Imbalenhle Community } \\
\text { Health Centre }\end{array}$ & Reduced inappropriate prescriptions by 53\% \\
\hline
\end{tabular}

analysis. Another government official from Bangladesh's Directorate General of Drug Administration (DGDA) overseeing medicines registration and pharmacovigilance activities remarked on the benefits of training approaches linked to improved quality of work or performance of the system:
"Established a system for pharmacovigilance; publish regular medicine safety reports and newsletters; monthly field visits; uploading ADR-related data [adverse drug reactions] through Vigiflow system. Adverse Drug Reaction Monitoring cell of DGDA was

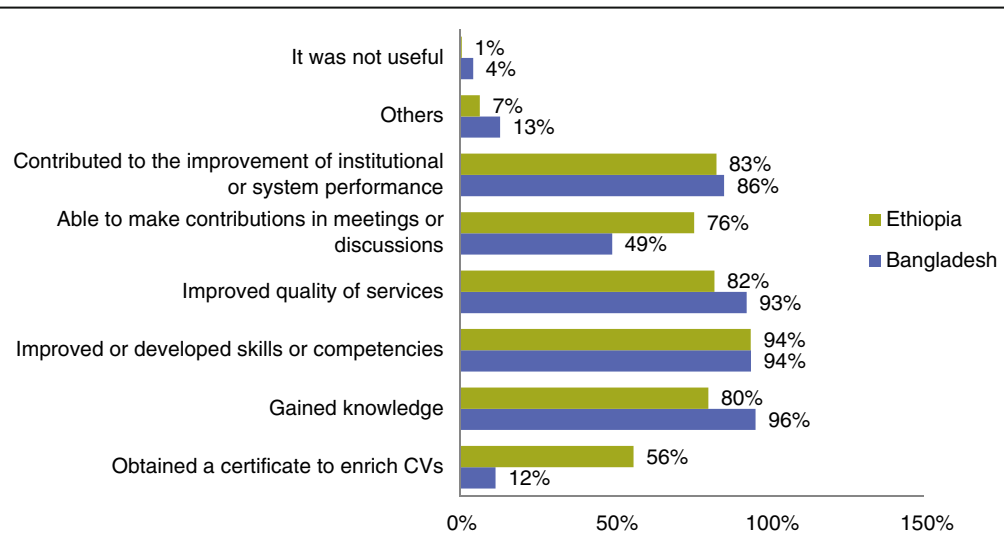

Fig. 3 Feedback on training: results from Ethiopia $(N=153)$ and Bangladesh $(N=69)$ 
awarded the 120th full membership of the WHO International Drug Monitoring Centre."

Figure 4 indicates trainee reported post-training factors that contributed to the achievement of results. A small number of individuals indicated the reasons for training not being helpful (Table 6). Among respondents in both countries, the factors that promoted ongoing use of skills in daily on-the-job activities and those that incorporated group sharing and learning were mentioned the most frequently. Supportive supervision structures that enabled the implementation of post-training action plans were also frequently mentioned. One respondent in Ethiopia commented on the importance of having ongoing, interactive training to continue to move programmatic activities forward:

"One can mention APTS [Auditable Pharmaceutical Transaction and Services] [56] where, with the creative approaches of [the program], 10 hospitals could be able to start APTS shortly after APTS training, unlike the classic trainings we know where staffs see training as means of a retreat. [The program's] mentoring [...] serves as a recipe for moving best practices forward ..."

Overall, the majority of the respondents cited systemsrelated support mechanisms and strong interpersonal support as important components related to the success of training efforts. Figure 5 provides a summary of the top eight preferred learning methods (see Additional file 2 for the entire list). The detailed reports for both Bangladesh and Ethiopia provides further information on the training approaches used and insights from key informant interviews [57].

\section{Discussion}

We provide a unique global implementer perspective regarding the variety of training approaches in the pharmaceutical system applied by country programs that fosters country ownership and sustainability consistent with other approaches [58]. Case-based learning, practice and feedback, and repetitive interventions such as post-training action plan, supportive supervision and mentoring approaches are effective, evidence-based training techniques applied by the program [59]. Individual capacity building efforts that include repetitive delivery and real-life case based trainings delivered positive results. South Africa's experience with the PLDP demonstrates that ongoing work-place based training that encourages people to solve real life work-related challenges is an effective, case-based training modality. Twenty years of lessons on capacity building from the World Bank Institute's Flagship Program also found that "rather than a one-way dumping of information through repeated PowerPoint sessions," case-based learning and team approaches are crucial for learning and health systems improvement [60]. The PLDP in South Africa and implementation of post-training action plans in other countries applied similar principles to the monitoring-trainingplanning approach that emphasizes responsibility for

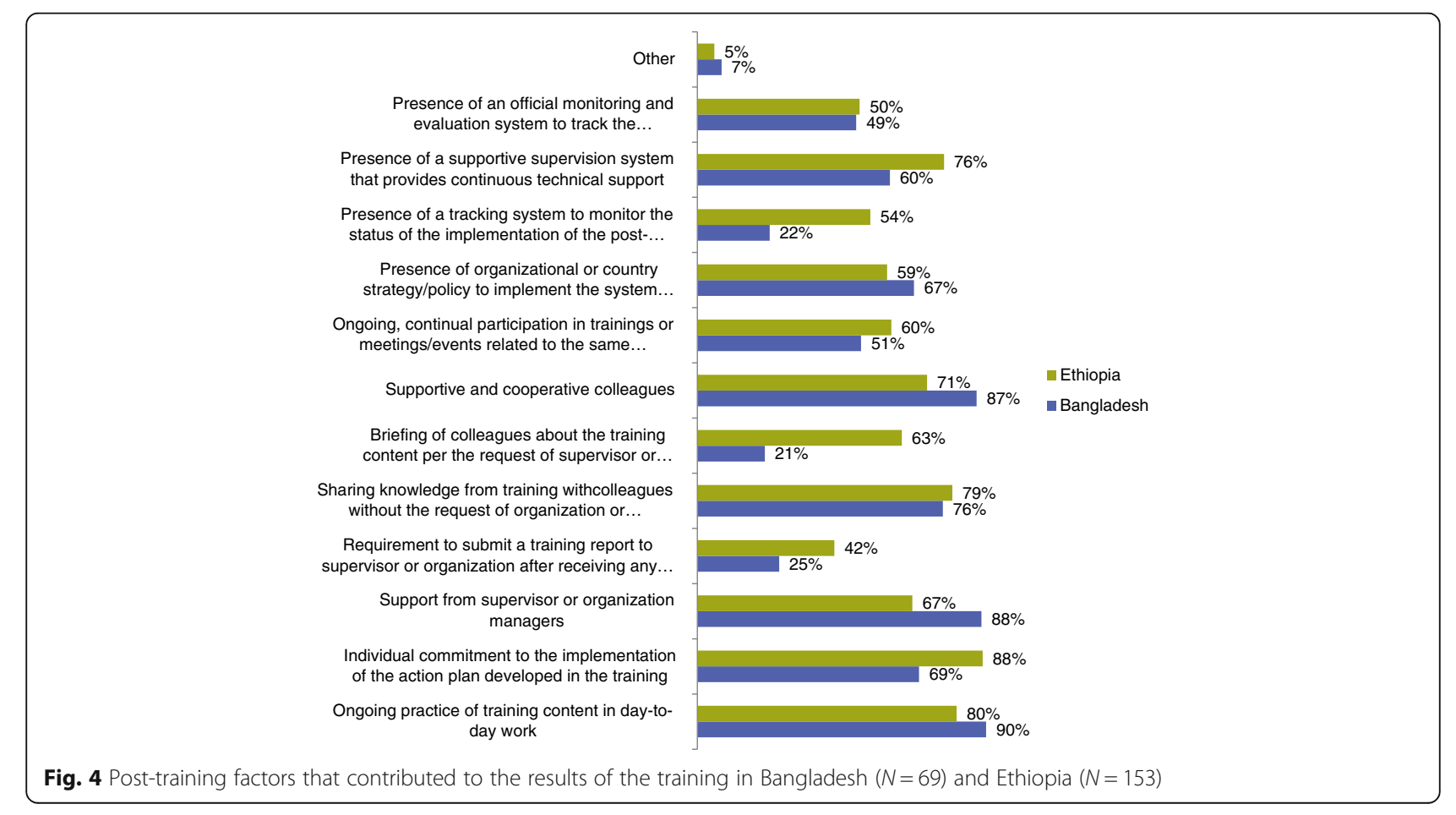


Table 6 Reasons why training was cited as not helpful

\begin{tabular}{lll}
\hline $\begin{array}{l}\text { Reason provided by trainees } \\
\text { surveyed }\end{array}$ & $\begin{array}{l}\text { Bangladesh } \\
(N=69)\end{array}$ & $\begin{array}{l}\text { Ethiopia } \\
(N=153)\end{array}$ \\
\hline $\begin{array}{l}\text { Training or capacity-building } \\
\text { approach was not interesting }\end{array}$ & 3 & 5 \\
$\begin{array}{l}\text { Training content was too } \\
\text { challenging to understand } \\
\text { and/or put into practice }\end{array}$ & 2 & 9 \\
$\begin{array}{l}\text { Training content or technical } \\
\text { area of the training did not } \\
\text { correspond with the } \\
\text { participants' work }\end{array}$ & 3 \\
$\begin{array}{l}\text { Appropriate environment was } \\
\text { not in place to enable } \\
\text { participants to use the } \\
\text { knowledge gained during the } \\
\text { training }\end{array}$ & 2 & 3 \\
\hline
\end{tabular}

implementing the pharmaceutical management practices learned in the hands of local staff [61]. Individual capacity training design tailored to the work environment and local context permit staff to receive ongoing and consistent feedback through multiple interventions with ongoing support from supervisors and peers [62].

Ensuring that strong systems are set up to bolster training activities is critical for those who are implementing individual capacity building efforts. Respondents from Bangladesh and Ethiopia perceived that both interpersonal support networks such as supportive supervision, and systems-level support mechanisms, such as aligned national and/or subnational strategies, improve the results of training as similar to the experience in Angola [63]. Yet, supportive supervision and mentoring which cost an annual average of US \$
1.2 million in just one district of South Africa for instance, must be adequately funded and institutionalized to mitigate the risk of not being planned and implemented [64]. Based on the experience from Mali, Namibia, South Africa and from other countries, the program ensured that supportive supervision structures and mentorship have been institutionalized with appropriate management structures. National authorities have been sensitized to secure funding from domestic resources or from the global fund grants for post-training follow-up initiatives.

Tailoring training activities to fit the local context is imperative for successful individual capacity building. Among the 12 selected countries reviewed, training was provided in several local languages: Amharic, Bangla, French, Portuguese and Ukrainian by local staff with the subject matter expertise frequently in collaboration with national and regional authorities. Over the years, the program took substantial efforts to have local staff deliver training and technical assistance interventions. The latter was acknowledged as "ethically sound" and culturally sensitive by leading educators at the Consortium of Universities for Global Health [65]. For specific topics that required international technical expertise such as pharmaceutical services, pharmacovigilance, regulatory systems strengthening, medicines registration, health technology assessment or digital health initiatives, interpretation would be provided in concert with rapid accessibility of translated training materials and job aids.

High turnover of staff challenges efforts to increase individual capacity of the workforce because training efforts alone are not sufficient to address larger issues relating to

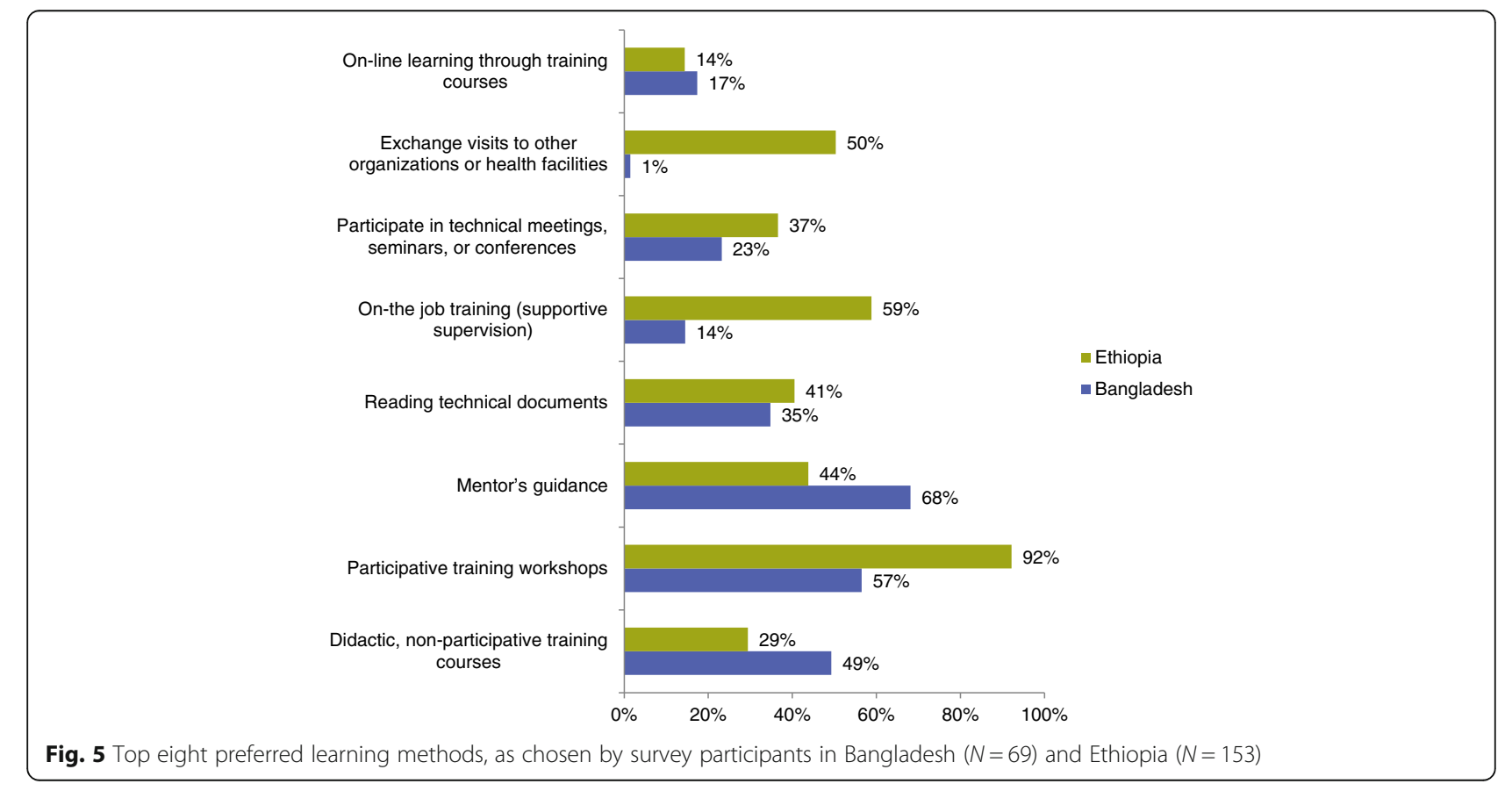


long-term recruitment and retention challenges. The Latin America model on facilitated distance learning for pharmaceutical services managers for continuous professional development may be replicated in the context of right enabling conditions and contribute to retention of health workers [66]. Interventions must involve local institutions in the design and delivery of content for both preservice and in-service training as well as web-based methods where feasible [67]. The Ethiopia program collaborated with several university teaching hospitals as a strategy to ensure sustained local capacity of pharmacists and health workers for the APTS intervention and supportive supervision activities $[68,69]$.

Our program experience has implications for those considering the future of pharmaceutical workforce development and training, given the High-Level Commission on Health Employment and Economic Growth's 10-point recommendations on investing in the health workforce to ensure progress towards the Sustainable Development Goals and to achieve Universal Health Coverage [70]. Effective pre-service training potentially reduces the need for future large-scale and expensive in-service trainings [71]. The program's experience demonstrate that competency based pre-service training will prepare students with a critical foundation of knowledge and skills required in the pharmaceutical system [72-74]. Sometimes, new topics such as pharmacovigilance [75], electronic medicines registration processes [76, 77], clinical pharmacy services [78, 79], patient-centered pharmaceutical care [80, 81], improving antibiotic prophylaxis [82] or medicines benefits package for universal health coverage [83] require comprehensive in-service and on-the-job training. The program's external evaluation found that national pharmaceutical system stakeholders are "increasingly concerned about the development of sustainable human capacity to support the growing demand for more and more sophisticated pharmaceutical services" and acknowledged the program's multi-pronged efforts [51]. The program's efforts complement the Nanjing statement on needs based approach through 13 global pharmaceutical workforce development goals for improving global health [84].

\section{Limitations}

Our selected review of the program's 12 implementing countries may be subject to selection bias because the program operated in more than 24 countries. Differences in training approaches and resulting data variation across countries and time contributes to limitations of this review. As a result, we are unable to compare data across countries. Moreover, because training events were developed for country-specific needs, training-related indicators were not applicable across all countries. Therefore, there was no way to compare training activities across countries and to generate trends at a global level. We do not elaborate the rationale in a country program's choice of a certain individual capacity building approach nor describe what did not work because there were multiple country-specific contextual factors that were not within the scope of this selected multi-country review. Because our focus was a selected review on modalities of training approaches in multiple countries based on the first 3 years of program implementation, we do not provide results on patient or health related outcomes associated with specific training interventions. The Bangladesh and Ethiopia trainee surveys included small sample sizes due to time and funding constraints. Yet our paper offers a unique implementer perspective supported with references to various country project documents.

\section{Conclusion}

Based on Potter and Brough's model, the program utilized a hierarchy of individual capacity building approaches that address the needs for tools (contextualized training curricula, job aids), skills (competency- and needs- based training design), and staff and facilities (training and post-training support). These three tiers build the foundation of improving the pharmaceutical system capacity. Program implementers must systematically collaborate with local institutions to provide coordinated training efforts that fill current skill shortage gaps, meet local needs in the pharmaceutical system, and promote the ownership of human capacity development interventions. Robust monitoring and evaluation efforts that are adequately funded must accompany individual capacity building programs to ensure that effective training methods are scaled up while those that are weak or ineffective are discontinued. Finally, training alone is not sufficient to address major human resource shortages and skill gaps. It must be paired with other system-level efforts to improve recruitment and retention of professionals.

\section{Additional files}

Additional file 1: Detailed methodology for surveys and key information interviews in Bangladesh and Ethiopia. (DOCX $30 \mathrm{~kb}$ )

Additional file 2: Learning Methods that Worked Best for the Respondents According to their Experiences. (DOCX $18 \mathrm{~kb}$ )

\section{Abbreviations}

ACPE: Accreditation Council for Pharmaceutical Education; APTS: Auditable Pharmaceutical Transaction and Services; B Pharm: Bachelor of Pharmacy; DGDA: Directorate General of Drug Administration [Bangladesh]; DR

Congo: Democratic Republic of the Congo; LMIS: Logistics Management Information System; NTP: National Tuberculosis Program:

PLDP: Pharmaceutical Leadership Development Program; TOT: Training of trainers; USAID: United States Agency for International Development; WHO: World Health Organization 


\section{Acknowledgements}

We thank Kimberly Grimmick, formerly with Management Sciences for Health for contributing to the study design and review. We appreciate the Bangladesh and Ethiopia country program team for their contribution in conducting the trainee survey. The contents of this manuscript would not have been possible without the dedicated and tireless efforts by the SIAPS country programs around the world who work in strong partnership with the Ministry of Health, private sector and local and international stakeholders to strengthen human capacity in pharmaceutical systems and services.

\section{Availability of data and materials}

Data supporting the manuscript findings are available as additional files. This work was made possible by the generous support of the American people through the US Agency for International Development (USAID, Washington DC, USA) Cooperative Agreement Number AID-OAA-A-11-00021. No funding bodies had any role in the study design, data collection, analysis, or decision to publish. The findings, opinions and conclusions in this article are those of the authors and do not necessarily represent the views and opinions of the SIAPS Program, Management Sciences for Health, USAID, or the US Government.

\section{Authors' contributions}

Country document content analysis design: SCW. Performed country desk review and analysis: SCW, TMLI, NK. Oversaw Bangladesh and Ethiopia survey data collection, interpretation and writing: SCW. Wrote the first draft of the manuscript: MR. Revised and finalized the manuscript: NK. Contributed to manuscript review: MR, SCW, TMLI. All authors read and approved the final version.

\section{Authors' information}

Megan Rauscher was affiliated with Pharmaceuticals and Health Technologies Group, Management Sciences for Health at the time of manuscript development.

\section{Competing interests}

The authors declare that they have no competing interests.

\section{Consent for publication}

Not applicable.

\section{Ethics approval and consent to participate}

Not applicable.

\section{Publisher's Note}

Springer Nature remains neutral with regard to jurisdictional claims in published maps and institutional affiliations.

\section{Author details}

${ }^{1}$ Systems for Improved Access to Pharmaceuticals and Services (SIAPS) Program, Management Sciences for Health, Arlington, VA, USA.

${ }^{2}$ Pharmaceuticals and Health Technologies Group, Management Sciences for Health, Arlington, VA, USA.

\section{Received: 28 January 2017 Accepted: 13 April 2017}

Published online: 08 May 2017

\section{References}

1. United Nations. Sustainable Development Goal 3: [Internet]. Sustainable Development Knowledge Platform. Available from: https:// sustainabledevelopment.un.org/sdg3. cited 24 Jan 2017.

2. Wirtz VJ, Hogerzeil HV, Gray AL, Bigdeli M, de Joncheere CP, et al. Essential medicines for universal health coverage. Lancet. 2016. doi: 10.1016/S01406736(16)31599-9.

3. Shubber Z, Mills EJ, Nachega JB, Vreeman R, Freitas M, Bock P, et al. PatientReported Barriers to Adherence to Antiretroviral Therapy: A Systematic Review and Meta-Analysis. PLoS Med. 2016;13(11):e1002183.

4. United Nations. High level meeting on antimicrobial resistance. Endorsed Political Declaration on AMR [Internet]. 2016. Available from http://www.un. org/pga/71/wp-content/uploads/sites/40/2016/09/DGACM_GAEAD_ESCABAMR-Draft-Political-Declaration-1616108E.pdf. cited 13 Jan 2017.
5. Hakkarainen KM, Hedna K, Petzold M, Hägg S. Percentage of patients with preventable adverse drug reactions and preventability of adverse drug reactions - a meta-analysis. PLoS One. 2012;7(3):e33236.

6. Pande S, Hiller JE, Nkansah N, Bero L. The effect of pharmacist-provided non-dispensing services on patient outcomes, health service utilisation and costs in low- and middle-income countries. Cochrane Database Syst Rev. 2013;28(2):CD010398.

7. Systems for Improved Access to Pharmaceuticals and Services (SIAPS). Enhancing Health Outcomes for Chronic Diseases in Resource-Limited Settings by Improving the Use of Medicines: The Role of Pharmaceutical Care, Submitted to the U.S. Agency for International Development by the SIAPS Program. Arlington: Management Sciences for Health; 2014. Available from: http://apps.who.int/medicinedocs/en/d/Js21523en/.

8. World Health Organization. Tackling the crisis of workforce shortages in the pharmaceutical sector. Geneva: World Health Organization; 2011. Available from: http://apps.who.int/medicinedocs/en/m/abstract/Js17997en/.

9. Bates I, John C, Bruno A, Fu P, Aliabadi S. An analysis of the global pharmacy workforce capacity. Hum Resour Health. 2016;14:61.

10. Hafner T, Walkowiak H, Lee D, Aboagye-Nyame F. Defining pharmaceutical systems strengthening: Concepts to enable measurement. Health Policy Plan. 2016. Advance Access. doi: 10.1093/heapol/czw153.

11. Systems for Improved Access to Pharmaceuticals and Services (SIAPS) Program. | SIAPS Program [Internet]. Available from: http://siapsprogram.org. cited 24 Jan 2017

12. Potter C, Brough R. Systemic capacity building: a hierarchy of needs. Health Policy Plan. 2004;19(5):336-45.

13. Systems for Improved Access to Pharmaceutical Services (SIAPS). Annual Report: Project Year 4, October 2014-September 2015, Submitted to the US Agency for International Development by the SIAPS Program. Arlington: Management Sciences for Health; 2015. Available from: http://apps.who.int/ medicinedocs/en/m/abstract/Js22239en/.

14. Chandani Y, Andersson S, Heaton A, Noel M, Shieshia M, Mwirotsi A, et al. Making products available among community health workers: Evidence for improving community health supply chains from Ethiopia, Malawi, and Rwanda. J Glob Health. 2014;4(2):20405.

15. Oqua D, Agu KA, Isah MA, Onoh OU, Iyaji PG, Wutoh AK, et al. Improving pharmacy practice through public health programs: experience from Global HIV/AIDS initiative Nigeria project. SpringerPlus. 2013;2:525.

16. WHO EMRO. Pre-service education. Child health and development [Internet]. Available from: http://www.emro.who.int/child-health/IMClpreservice-training/what-is-it. cited 24 Jan 2017.

17. Systems for Improved Access to Pharmaceuticals and Services (SIAPS). Revising Preservice Curriculum to Incorporate Rational Medicine Use Topics: A Guide, Submitted to the US Agency for International Development by the SIAPS Program. Arlington: Management Sciences for Health; 2013. Available from: http://apps.who.int/medicinedocs/en/d/Js21526en/.

18. Strengthening Pharmaceutical Systems. Strengthening Pharmaceutical Services Program Final Report: 2007-2012, Submitted to the US Agency for International Development by the Strengthening Pharmaceutical Systems (SPS) Program. Arlington: Management Sciences for Health; 2013. Available from: http://pdf.usaid.gov/pdf_docs/pdacy204.pdf.

19. Minh PD, Huong DT, Byrkit R, Murray M. Strengthening pharmacy practice in Vietnam: findings of a training intervention study. Trop Med Int Health. 2013;18(4):426-34. doi:10.1111/tmi.1206.

20. Bradley S, Kamwendo F, Masanja H, de Pinho H, Waxman R, Boostrom C, McAuliffe E. District health managers' perceptions of supervision in Malawi and Tanzania. Hum Resour Health. 2013;11:43. doi:10.1186/1478-4491-11-43.

21. Namagembe A, Ssekabira U, Weaver MR, Blum N, Burnett S, Dorsey G, Sebuyira LM, Ojaku A, Schneider G, Willis K, Yeka A. Improved clinical and laboratory skills after team-based, malaria case management training of health care professionals in Uganda. Malar J. 2012;11:44. doi:10.1186/1475-2875-11-44.

22. Swanson RC, Cattaneo A, Bradley E, Chunharas S, Atun R, Abbas KM, Katsaliaki K, Mustafee N, Mason Meier B, Best A. Rethinking health systems strengthening: key systems thinking tools and strategies for transformational change. Health Policy Plan. 2012;27 Suppl 4:iv54-61.

23. Frehywot $\mathrm{S}$, Vovides $Y$, Talib Z, Mikhail N, Ross $H$, Wohltien $H$, Bedada S, Korhumel K, Koumare AK, Scott J. E-learning in medical education in resource constrained low- and middle-income countries. Hum Resour Health. 2013;11:4. doi:10.1186/1478-4491-11-4.

24. Brock T, Wuliji T, Sagwa E, Mabirizi D. Technical Report: Exploring the Establishment of a Pharmacy Course at the University of Namibia, March 
12-27, 2009, Submitted to the U.S. Agency for International Development by the Strengthening Pharmaceutical Systems (SPS) Program. Arlington: Management Sciences for Health; 2009. Available from: http://pdf.usaid.gov/ pdf_docs/Pnadu430.pdf.

25. University of Namibia. Overview of the School of Pharmacy [Internet]. Available from: http://www.unam.edu.na/school-of-pharmacy. cited 24 Jan 2017.

26. Mazibuko G, Phulu B, Sagwa E, Kibuule D, Kagoya H, Mavu D. Support to local training institutions to address human resources shortages and capacity affecting ART service delivery in Namibia, Submitted to the US Agency for International Development by the Systems for Improved Access to Pharmaceuticals and Services (SIAPS) Program. Arlington: Management Sciences for Health; 2014.

27. Rennie T, Kibuule D, Haoses-Gorases L, Nyarang'o P, Mabirizi D, Sagwa E, et al. Namibia's First School of Pharmacy: From Creation to Graduation, Systems for Improved Access to Pharmaceuticals and Services (SIAPS) Program. Arlington: Management Sciences for Health; 2015. Available from: http://siapsprogram.org/2015/04/27/namibias-first-school-of-pharmacy-fromcreation-to-graduation/.

28. Systems for Improved Access to Pharmaceuticals and Services (SIAPS) Program. Technical Brief: Strengthening Namibia's Pharmacy Sector and Workforce. Arlington: Management Sciences for Health; 2016. Available from: http://siapsprogram.org/publication/technical-brief-strengtheningnamibias-pharmacy-sector-and-workforce/.

29. Kibuule D, Lates J, Niaz Q, Mazibuko G, Phulu B, Kagoya HR, et al. Concept and Guidelines for Medicine Use Assessment during Students' Rural Placements. Submitted to the US Agency for International Development by the MoHSS-NHTC with support from the SIAPS program. Management Sciences for Health: Arlington; 2015. Available from: http://apps.who.int/ medicinedocs/en/m/abstract/Js22148en/.

30. Kutenda O, Leboea J, Kambyambya K, Mavu D, Kagoya H, Mazibuko G, et al. Post-qualification Monitoring and Evaluation of Pharmacist Assistants Trained at the National Health Training Centre in Namibia, Submitted to the US Agency for International Development by the MoHSS-NHTC with support from the Systems for Improved Access to Pharmaceuticals and Services program. Arlington: Management Sciences for Health; 2015. Available from: http://siapsprogram.org/publication/post-qualificationmonitoring-and-evaluation-of-pharmacist-assistants-trained-at-the-nationalhealth-training-centre-in-namibia/.

31. Accreditation Council for Pharmaceutical Education (ACPE). About ACPE [nternet]. Available from https:/wnw.acpe-accredit.org/about/. cited 24 Jan 2017.

32. Vlasses P, Grégoire J. Recommendations for Advancing Pharmacy Education in the Democratic Republic of the Congo, Submitted to the US Agency for International Development by the Systems for Improved Access to Pharmaceuticals and Services (SIAPS) Program. Management Sciences for Health: Arlington; 2014. Available from http:/apps.who.int/medicinedocs/en/d/Js21918en/.

33. Anderson C, Bates I, Brock T, Brown AN, Bruno A, Futter B, et al. Needs-Based Education in the Context of Globalization. Am J Pharm Educ. 2012;76(4):56.

34. Rouse M, Vlasses P, Wadelin J, Zarembski D, Joshi MP, Mabirizi D, Saleeb S. Continuing Pharmaceutical Education: Guide to Establishing Quality Assured and Accredited Programs, Submitted to the US Agency for International Development by the Systems for Improved Access to Pharmaceuticals and Services (SIAPS) Program. Arlington: Management Sciences for Health; 2016. Available from http://apps.who.int/medicinedocs/en/m/abstract/Js22394en/.

35. USAID Works to Improve Quality of Pharmacist Training [nternet]. U.S. Embassy in the Democratic Republic of the Congo. 2015. Available from: https://cd.usembassy. gov/usaid-works-improve-quality-pharmacist-training/. cited 24 Jan 2017.

36. Systems for Improved Access to Pharmaceuticals and Services (SIAPS). e-TB Manager Promotes Treatment Quality and Evidence-Based Forecasting of TB Medicines. Arlington: Management Sciences for Health; 2015. Available from: http://siapsprogram.org/publication/e-tb-manager-promotes-treatmentquality-and-evidence-based-forecasting-of-tb-medicines-in-ukraine/.

37. Systems for Improved Access to Pharmaceuticals and Services (SIAPS). Institutionalizing e-TB Manager as a national TB registry in Ukraine [Internet]. Arlington: Management Sciences for Health; 2015. Available from: http:// siapsprogram.org/2015/11/04/institutionalizing-e-tb-manager-as-a-nationaltb-registry-in-ukraine/.

38. Systems for Improved Access to Pharmaceuticals and Services (SIAPS). Strengthening Pharmaceutical Services through Structured Supportive Supervision in Namibia. Arlington: Management Sciences for Health; 2015. Available from: http://siapsprogram.org/publication/strengtheningpharmaceutical-services-through-structured-supportive-supervision-in-namibia/.
39. Systems for Improved Access to Pharmaceutical Services (SIAPS). Annual Report: Project Year 3, October 2013-September 2014. Submitted to the US Agency for International Development by the SIAPS Program. Arlington: Management Sciences for Health. Available from: http://apps.who.int/ medicinedocs/en/d/Js21707en/.

40. Systems for Improved Access to Pharmaceuticals and Services (SIAPS). Design, Implementation, and Use of Pharmaceutical Logistics Management Information Systems (LMIS): SIAPS Technical Brief. Arlington: Management Sciences for Health; 2016. Available from: http:/siapsprogram.org/publication/Imis-technical-brief-theusaid-siaps-best-practices-in-the-design-implementation-and-use-ofpharmaceutical-logistics-management-information-systems/.

41. Kniazkov S, Savchuk T. Framework Contracting in Ukraine: A Story of Success. Submitted to the US Agency for International Development by the Systems for Improved Access to Pharmaceuticals and Services (SIAPS) Program [Internet]. Management Sciences for Health; 2015. Available from: http://apps. who.int/medicinedocs/en/m/abstract/Js22280en/. cited 24 Jan 2017.

42. Sullivan TM, Limaye RJ, Mitchell V, D'Adamo M, Baquet Z. Leveraging the Power of Knowledge Management to Transform Global Health and Development. Glob Health Sci Pract. 2015;3(2):150-62.

43. USAID. Global Health e-Learning Center. Courses [Internet]. Available from: https://www.globalhealthlearning.org/courses. cited 24 Jan 2017.

44. Essential Medicines and Health Products Information Portal [Internet]. Available from: http://apps.who.int/medicinedocs/en/. cited 17 Jan 2017.

45. University of the Western Cape. Online Rational Medicines Use Module. Schools of Public Health and Pharmacy in collaboration with SIAPS program and other partners. South Africa. Available at https:/www.uwc.ac.za/Faculties/ $\mathrm{CHS} /$ soph/News/Pages/NEW-Online-Rational-Medicines-Use-Module.aspx.

46. Management Sciences for Health. LeaderNet. QuanTB online course. Systems for Improved Access to Pharmaceuticals and Services (SIAPS) Program [Internet]. Available from: http://leadernet.org/groups/courses/ quantb/. cited 24 Jan 2017

47. Bradley H, Lehmann U, Butler N. Emerging roles and competencies of district and sub-district pharmacists: a case study from Cape Town. Hum Resour Health. 2015;13:88.

48. Tools and Approaches: Developing Effective Leaders for Stronger Health Systems [Internet]. Medford, MA: Management Sciences for Health [Internet]. Available from: https://www.msh.org/sites/msh.org/files/msh_ leadership_brochure.pdf. cited 24 Jan 2017.

49. Mansour M, Mansour JB, Swesy AHE. Scaling up proven public health interventions through a locally owned and sustained leadership development programme in rural Upper Egypt. Hum Resour Health. 2010;8:1.

50. Seims LR, Alegre JC, Murei L, Bragar J, Thatte N, Kibunga P, Cheburet S. Strengthening management and leadership practices to increase health-service delivery in Kenya: an evidence-based approach. Hum Resour Health. 2012;10:25.

51. Carrino C, Miralles M, Whitworth R. Interim evaluation of Systems for Improved Access to Pharmaceuticals and Services (SIAPS) Project. Submitted by GH PRO project to USAID; 2016 May. Report No.: 3001-083. Available from: http://pdf.usaid.gov/pdf_docs/pa00m7qr.pdf.

52. Putter S, Mkele G, Mkandawire T, Nene N, Payne K, Tindula C. Technical Report: South Africa Pharmaceutical Leadership Development Program (PLDP), Submitted to the US Agency for International Development by the Systems for Improved Access to Pharmaceuticals and Services (SIAPS) Program. Arlington: Management Sciences for Health; 2015. Available from: http://siapsprogram.org/publication/technical-report-south-africapharmaceutical-leadership-development-program/.

53. Systems for Improved Access to Pharmaceuticals and Services. Dashboard module reduces contraceptive stock-outs at SDPs in Bangladesh. SIAPS Technical Highlight. Arlington: Management Sciences for Health; 2016. Available from: http://siapsprogram.org/publication/technical-highlightdashboard-module-reduces-contraceptive-stock-outs-at-sdps-in-bangladesh/.

54. Systems for Improved Access to Pharmaceuticals and Services. Video: Reducing Stock-outs and Saving Lives in Bangladesh, [Internet]. Arlington: Management Sciences for Health; 2016. Available from: http://siapsprogram. org/2016/11/30/video-reducing-stock-outs-and-saving-lives-in-bangladesh/.

55. Systems for Improved Access to Pharmaceuticals and Services (SIAPS). Logistics Management Units Improve Availability of Medicines in Bangladesh. Arlington: Management Sciences for Health; 2015. Available from: http://siapsprogram.org/publication/logistics-management-unitsimprove-availability-of-medicines-in-bangladesh/.

56. Sheckler A. How One Pharmacist Can Make a Difference: Transforming Ethiopia's Pharmaceutical Sector. Frontline Health Workers Coalition; 2014 
Available from: https:/www.frontlinehealthworkers.org/how-one-pharmacistcan-make-a-difference-transforming-ethiopias-pharmaceutical-sector/.

57. Systems for Improved Access to Pharmaceuticals and Services. Selected Review of Training Approaches in the SIAPS Program: Bangladesh and Ethiopia Country Reports. Arlington: Management Sciences for Health; 2016. Available from: http://siapsprogram.org/publication/selected-review-of-trainingapproaches-in-the-siaps-program-bangladesh-and-ethiopia-country-reports/.

58. Cancedda C, Farmer PE, Kerry V, Nuthulaganti T, Scott KW, Goosby E, et al. Maximizing the Impact of Training Initiatives for Health Professionals in Low-Income Countries: Frameworks, Challenges, and Best Practices. PLoS Med. 2015;12(6):e1001840.

59. Bluestone J, Johnson P, Fullerton J, Carr C, Alderman J, BonTempo J. Effective in-service training design and delivery: evidence from an integrative literature review. Hum Resour Health. 2013;11:51.

60. Reich MR, Yazbeck AS, Berman P, Bitran R, Bossert T, et al. Lessons from 20 Years of Capacity Building for Health Systems Thinking. Health Syst Reform. 2016;2(3):213-21.

61. Rational Pharmaceutical Management Plus Program. A Guide for Implementing the Monitoring-Training-Planning (MTP) Approach to Build Skills for Pharmaceutical Management, Submitted to the U.S. Agency for International Development by the Rational Pharmaceutical Management Plus Program. Arlington: Management Sciences for Health; 2009. Available from: https://www.k4health.org/toolkits/leadershipmgmt/guideimplementing-monitoring-training-planning-mtp-approach-build-skills.

62. Wang S, Hoohlo N, Tshabalala K, Ntoi K, Sepetla T. Capacity Needs Assessment for Pharmaceutical Services for the ART Program in Lesotho, Submitted to the US Agency for International Development by the Systems for Improved Access to Pharmaceuticals and Services (SIAPS) Program. Arlington: Management Sciences for Health; 2013. Available from: http:// apps.who.int/medicinedocs/en/d/Js21831en/.

63. Joao L. Improving Supply Chain Management for Malaria: Lessons from Angola. Management Sciences for Health; 2015. Available from: https:// www.msh.org/news-events/stories/improving-supply-chainmanagement-formalaria-lessons-from-angola.

64. Johnson S. Cost implications and benefits of using Roving Mentor Teams to strengthen HIV and TB clinical management in public sector primary care clinics. Presentation at the PEPFAR partner dissemination meeting: Reaching 90-90-90 in South Africa Part III: Best Practices and Innovations in Linkage, Treatment and Viral Suppression. 2016. US Embassy South Africa. Available from: https:/za.usembassy.gov/our-relationship/pepfar/partner-disseminationmeetings/reaching-90-90-90-south-africa-part-iii-presentations/.

65. Eichbaum Q, Evert J, Hall T. Will there be enough jobs for trained global health professionals? Lancet Glob Health. 2016;4(10):e692-3.

66. Emmerick IC, Chaves LA, Marin N, Luiza VL. Strengthening the capacity of managers in pharmaceutical services based on Primary Health Care (PHC) at different levels of the health system. Hum Resour Health. 2014;12:34.

67. Matowe L, Waako P, Adome RO, Kibwage I, Minzi O, Bienvenu E. A strategy to improve skills in pharmaceutical supply management in East Africa: the regional technical resource collaboration for pharmaceutical management. Hum Resour Health. 2008;6:30.

68. University of Gonder Teaching Hospital. University of Gondar Hospital Launches Auditable Pharmaceutical Transaction and Service (APTS). Available from: http://www.uog.edu.et/university-gondar-hospital-launchesauditable-pharmaceutical-transaction-service-apts/.

69. Tadeg H, Ejigu E, Geremew E, Adinew A. Auditable Pharmaceutical Transactions and Services (APTS): Findings of the Baseline Assessment at Federal, Addis Ababa, and Teaching Hospitals, Submitted to the US Agency for International Development by the Systems for Improved Access to Pharmaceuticals and Services (SIAPS) Program. Arlington: Management Sciences for Health; 2013. Available from: http://apps.who.int/medicinedocs/ en/d/ss21704en/.

70. World Health Organization. UN Commission: New investments in global health workforce will create jobs and drive economic growth. 2016. Available from: http://www.who.int/mediacentre/news/releases/2016/globalhealth-workforce/en/.

71. Youmans S, Ngassapa O, Chambuso M. Clinical pharmacy to meet the health needs of Tanzanians: education reform through partnership across continents (2008-2011). J Public Health Policy. 2012;33 Suppl 1:S110-25.

72. General Directorate of Pharmaceutical Affairs and, General Directorate of Human Resources, General Directorate of Pharmaceutical Affairs and. Competency Framework for Pharmaceutical Services [Internet]. Islamic
Republic of Afghanistan Ministry of Public Health; 2012. Available from: http://apps.who.int/medicinedocs/en/d/Js21747en/.

73. Joshi M, Ludman M, Kibuule D, Rennie T, Lates J, Knott M, et al. Strengthening Pre-service Pharmacy Training on Rational Medicine Use and Antimicrobial Resistance, Submitted to the US Agency for International Development by the Systems for Improved Access to Pharmaceuticals and Services Program. Arlington: Management Sciences for Health; 2014. Available from: http://apps.who.int/medicinedocs/en/m/abstract/Js21528en/.

74. Systems for Improved Access to Pharmaceuticals and Services (SIAPS). SIAPS' Capacity Building Efforts to Improve the Dominican Republic's Health Management System. Arlington: Management Sciences for Health; 2016. Available from: http://siapsprogram.org/publication/siaps-capacity-buildingefforts-to-improve-the-dominican-republics-health-management-system/.

75. Systems for Improved Access to Pharmaceuticals and Services (SIAPS) Program. Strengthening Bangladesh's National Pharmacovigilance System: Lessons Learned and Opportunities. Arlington: Management Sciences for Health; 2016. Available from: http://siapsprogram.org/publication/strengthening-bangladeshsnational-pharmacovigilance-system-lessons-learned-and-opportunities/.

76. Kim EM. Strengthening the Medicine Regulatory System by Implementing an Electronic Medicine Registration Data Management System (Pharmadex) in Mozambique, Submitted to the US Agency for International Development by the Systems for Improved Access to Pharmaceuticals and Services (SIAPS) Program. Arlington: Management Sciences for Health; 2016. Available from: http://apps.who.int/medicinedocs/en/d/Js22438en/.

77. Aimiuwu J. Improving the Process of Medicines Registration in Bangladesh: Adoption of the Common Technical Document Format and Implementation of Pharmadex to Automate the Registration of Medicines, Submitted to the US Agency for International Development by the Systems for Improved Access to Pharmaceuticals and Services (SIAPS) Program. Arlington: Management Sciences for Health; 2016. Available from: http:// apps.who.int/medicinedocs/en/d/Js23064en/.

78. Geremew E, Worku F, Hailu T, Ejigu E, Mekonnen N. Building Local Capacity for Clinical Pharmacy Service in Ethiopia through a Holistic In-Service Training Approach, Submitted to the US Agency for International Development by the Systems for Improved Access to Pharmaceuticals and Services (SIAPS) Program. Arlington: Management Sciences for Health; 2014. Available from: http://apps.who.int/medicinedocs/en/d/Js21810en/.

79. Agu KA, Oqua D, Agada P, Ohiaeri SI, Adesina A, Abdulkareem MH, et al. Assessment of satisfaction with pharmaceutical services in patients receiving antiretroviral therapy in outpatient HIV treatment setting. Int I Clin Pharm. 2014;36(3):636-47.

80. Systems for Improved Access to Pharmaceuticals and Services (SIAPS). Systems Improving Health Outcomes through Delivery of Patient-Centered Pharmaceutical Care by Pharmacists in Low- and Middle-Income Countries. Technical Brief. Arlington: Management Sciences for Health; 2016. Available from: http://siapsprogram.org/publication/technical-brief-improving-healthoutcomes-through-delivery-of-patient-centered-pharmaceutical-care-bypharmacists-in-low-and-middle-income-countries/.

81. Agu KA, Oqua D, Adeyanju Z, Isah MA, Adesina A, Ohiaeri SI, et al. The incidence and types of medication errors in patients receiving antiretroviral therapy in resource-constrained settings. PLoS One. 2014;9(1):e87338.

82. Gammouh S, Joshi M. Improving Antibiotic Prophylaxis in Cesarean Section in Jordanian Hospitals: SIAPS Technical Report, Submitted to the US Agency for International Development by the Systems for Improved Access to Pharmaceuticals and Services (SIAPS) Program. Arlington: Management Sciences for Health; 2013. Available from: http://apps.who.int/medicinedocs/ en/d/Js21698en/.

83. Wagner AK, Quick JD, Ross-Degnan D. Quality use of medicines within universal health coverage: challenges and opportunities. BMC Health Serv Res. 2014;14:357.

84. International Pharmaceutical Federation. Pharmaceutical Workforce Development Goals. Global Conference on Pharmacy and Pharmaceutical Sciences Education. Nanjing; 2016. Available from: http://www.fip.org/ nanjing2016/.

85. Systems for Improved Access to Pharmaceuticals and Services (SIAPS). Strengthening the Leadership and Management of Pharmaceutical Services in South Africa: SIAPS Technical Brief. Arlington: Management Sciences for Health; 2016. Available from: http://siapsprogram.org/publication/technicalbrief-strengthening-the-leadership-and-management-of-pharmaceuticalservices-in-south-africa/. 